\title{
MEMORY STUDIES
}

\section{Artistic and activist memory-work: Approaching place-based practice}

\author{
KAREN E. TILL, University of Minnesota, USA
}

\begin{abstract}
While an emerging interdisciplinary field of memory studies exists, what it is and might become remains open to debate. This article calls for a memory studies agenda that remains sensitive to the ways individuals and groups experience memory as multisensual, spatial ways of understanding their worlds. Artistic and activist memory-work in particular offers at least two contributions to such an agenda. It challenges ontological assumptions that underpin much of the recent interdisciplinary body of research on memory, including understandings of site, social and body memory, and the role of place in memory; and it invites scholars to consider their research in terms of socially responsible place-based practice. In this article, I discuss sites of social engagement, embodied and social memory, and wounded places to consider how artistic and activist place-based practice might fundamentally change how memory studies scholars think about their research.
\end{abstract}

\section{Key words}

artistic practice; body memory; place; politics of memory; site; wounded cities

\section{Site}

Program note: site is a project that has been a year in the making. When I returned from Australia to visit Cape Town I learned the story of the skeletons. It began with an accidental discovery. On a building site situated in the heart of the city, construction workers found one skeleton in 2003. Under heritage law in South Africa, the developer is responsible for covering the costs of an archaeological team. They soon found a sum total of three thousand bodies, packed on top of each other, layer after layer, dating back to the beginnings of Dutch colonisation. This burial ground at Prestwich Street was the largest of its kind in the country. A similar incident dating back to Dutch colonial days had already occurred in New York in the mid-nineties, 
but it was of a smaller scale and had an altogether different resonance than the discovery in post-apartheid Cape Town.

The building site where the bodies were found was located just outside the old coIonial walls of the city. This indicated that they were not of Dutch Reformed origin, setting up an interesting debate. As with most of recorded history, underclass groups are remembered across generations largely through the tradition of oral rather than written history. Here was an opportunity for academic study. Forensic anthropologists and archaeologists were keen to investigate the identities of these bodies in order to learn more of Cape Town's history. But the study of skeletons in the past has been fraught with colonial-racist undertones. And in a country desperately trying also to recover from decades of the racist effects of apartheid and forced removals, removing bodies for the sake of developing a site is no easy task. Community groups rose up against the removal and study of these bodies, and there began a struggle of voices and perspectives.

South Africa has come through a dramatic change over the past twelve years and questions of progress, memory, reconciliation, identity and the past are spoken about at large. I felt very privileged to be a part of a memory methodology workshop held in Cape Town in 2005 that attempted to deal with the traumas of forced removals. It sparked my interest in how trauma is translated through generations and through time. When I returned to Australia a few months later and began working on site, I realised that these kinds of debates were not being spoken as frequently or as freely. The traumas of the past in Australia didn't seem to be confronted on an everyday level and I wondered what this meant for Australian identity. If Melbourne were to rub her skin raw, what would she find? And perhaps more poignantly how would she deal with it?

(Talya Chalef, April 2006) ${ }^{1}$

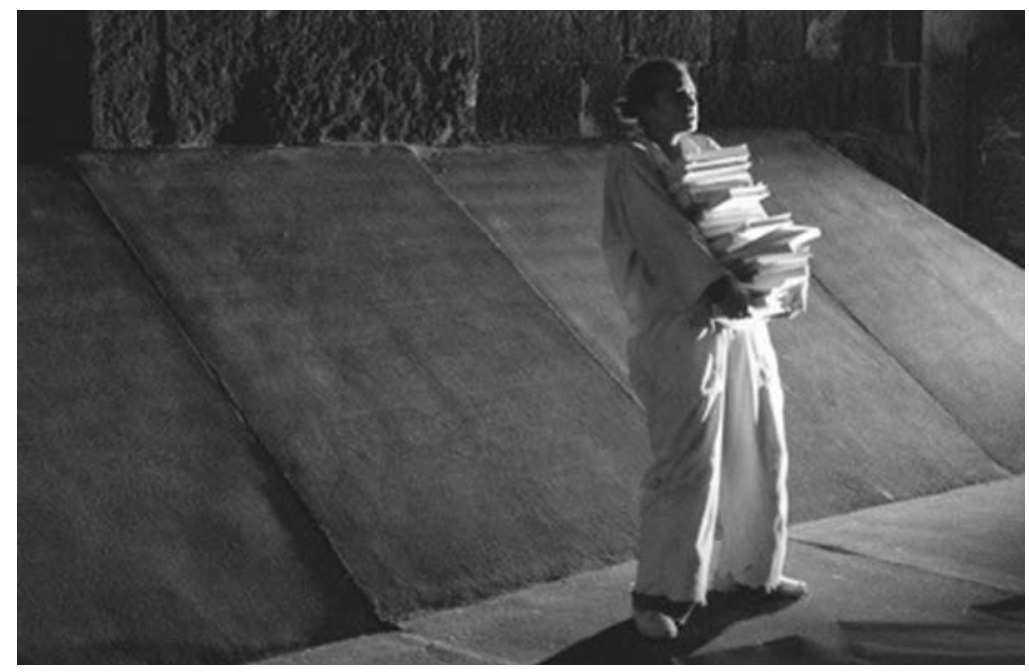

FIGURE 1 Performance artist Tanya Heyward in site, Melbourne Watch House, 2006 (C) Talya Chalef. Photograph by Bronwyn Pringle, courtesy of the artist. 
In postcolonial cities such as Cape Town and Melbourne, the lingering presence of past lives cannot be simply relegated to archival documents or historical narratives. Places such as the Prestwich Street burial ground are haunted locales through which unfolding and intersecting social and personal histories resonate across space and time (Jonker and Till, 2007). In describing her inspiration for site (Figures 1 and 3), artist Talya Chalef reveals the multi-scaled temporal and spatial coordinates that emerged through a particular place: her return to Cape Town; learning about the burial ground; the construction workers' discovery of human remains; its 'foreign' location on colonial maps and central location on developers' maps; the unrecorded voices of the colonial underclasses that inspired activists; the archaeologists' desire to study these bones; the ongoing pain of colonial and apartheid displacements; the debates over belonging in South Africa; and the relative silence about these issues in Australia. She reminds us that the burial ground was no mere site: through this particular place the living came into contact with past lives and began to imagine more socially just futures.

Scholars engaged in research about memory have much to gain by paying attention to works by artists such as Chalef and activists who also acknowledge the ways that people experience memory as multi-sensual, spatial ways of understanding their worlds. Indeed, in recent discussions about memory in disciplinary and interdisciplinary research, as found in dictionary and encyclopedia entries, review anthologies, funded grant proposals, conference sessions, articles, websites, special journal issues and edited volumes, debates have emerged about memory as a process, way of knowing and object of study. Although scholars have described artistic projects and, to a lesser degree, grassroots and activist movements as part of these discussions, they rarely involve themselves with artistic and activist place-based memory practice.

Memory studies is now acknowledged institutionally as a field of interdisciplinary inquiry as evidenced by specialized academic journals and degree programs. ${ }^{2}$ Beginning as topic of study in the 1970s and 1980s that focused on the emergence of the so-called memory industry - a seemingly contradictory phenomenon expressed through state-funded, popular and counter-memory projects - scholars analyzed heritage projects, memorialization and museumification, and fragmentary forms of literature, art and new memory technologies as responses to such (western) uncertainities as postmodern identity politics; new data and information storage and surveillance systems; an aging generation of Holocaust survivors; and political traumas and economic shifts accompanying a postcolonial, postindustrial, postmodern and later post-Cold War world. More recent discussions, while including a diversity of viewpoints, methodological approaches and research agendas, now focus on such topics as the politics of public memory and official forgetting at national and international scales; the differences (or not) between individual and social memory; the distinctions between 'types' of memory (cognitive, procedural, habitual, bodily, sensory, narrative, traumatic, to name a few); the intersections between memory, embodiment, representation, materiality and the psyche; and the dialectical relationship of memory and forgetting.

As these general areas of interest suggest, while a loosely defined interdisciplinary field of memory studies exists, what it is and might become remains open to debate. In this article, I call for a memory studies agenda that remains sensitive to the ways individuals 
and groups understand their pasts and possible futures through the relationships they and others have with place. As I argue in this article, artistic and activist memory-work has much to offer the emerging field of memory studies by challenging ontological assumptions that underpin much recent research on memory, including understandings of site, social and body memory, and the role of place in memory. ${ }^{3}$ More than this, artistic and political engagements with memory call us, as individuals and members of various communities, to move beyond claims to interdisciplinarity within academia and consider how memory studies might develop more socially responsible research practices. Below, I discuss sites of social engagement, embodied and social memory, and wounded places to consider how place-based artistic and activist practice can contribute to defining what memory studies might become.

\section{RETHINKING SITE: MEMORY-WORK AS SOCIAL ENGAGEMENT}

site takes a complex set of issues and translates them into a context that is accessible to those who would not otherwise have access to a dialogue about the possibilities of social change. Locating site at the decommissioned 'Watch House' on Russell Street will encourage Melbourne audiences to question the performance experience in relation to their own understandings.

(Talya Chalef, Australian National Trust grant application for site, 2005) ${ }^{4}$

Chalef's goal of creating a dialogue with diverse audiences through performance and story-telling is indicative of a recent development in socially engaged site-specific art. Since the 1970s, activists and artists alike have questioned traditional understandings of site as abstract location and called for an art of place that encourages conversations about contemporary issues, including social memory (Hayden, 1995; Lacy, 1995; Rassool and Prosalendis, 2001; Dorrian and Rose, 2003; Kester, 2004; Kwon, 2004). Yet the abstract concept site - a Cartesian location imprinted by historical events - continues to be the spatial unit of analysis for most academics that study memory, despite Edward Casey's (1987) arguments about the significance of place in remembering. ${ }^{5}$ Inspired by Pierre Nora $(1989,1997)$, scholars analyze lieux of memory according to when sites emerge, why they take particular forms (stamps, parades, archives, street names) and how they work as nodes within a larger, albeit changing, national commemorative topography. While providing a range of excellent histories, counter-histories, and discussions about lieux and non-lieux de mémoire, this 'biography of a site' approach is a limited way of understanding memory, one that assumes distinctions between time and space, interior and exterior worlds, and the individual and the social (Till 2003, 2006). ${ }^{6}$

Place-based and site-specific artistic practice, in contrast, includes environmental projects, student exhibitions and multi-media participatory political actions. Performance collective Border Art Workshop/Taller de Arte Fronterizo based in San Diego, California, for example, use a range of public media (billboards, bus signs, faxes, neighborhood 
performances) to call attention to the US-Mexico borderlands as 'a terrain of great tragedy, but [as] a place where social upheaval also produces the possibility of constructive transformation of both Mexican and American cultures' (Pincus cited in Lacy 1995: 206). Their 1990 Border Sutures month-long performance journey traversed the border in zigzag fashion, 'during which participants made a variety of staples that attempted to heal the wound of the border and involved people along the line' (Border Art Workshop/Taller de Arte Fronterizo, 2007). Their border crossing points, as nontraditional artistic sites, created new networks of communication between workshop members, native Americans, Mexicans and North Americans, all of whom contributed to a socially engaged form of memory-work through site-specific (re)makings of a traumatized region.

Human rights activists too have reframed traditional understandings of historic site by establishing active places of memory that are more than locations of past events or nodes of national topographies. Drawing international attention to their work, recently established coalitions of 'memorial museums to victims of public crimes' and 'historic site museums of conscience' include places such as the Perm-36 Gulag Museum in Russia, Memoria Abierta (Open Memory) in Argentina, the Japanese-American National Museum in the USA, the Liberation War Museum in Bangladesh, and the Topography of Terror International Documentation Center in Germany. ${ }^{7}$ These hybrid memorialresearch-social outreach centers include historical exhibitions, educational programs and community events; some provide therapeutic spaces for displaced individuals. The District Six Museum in Cape Town, for example, originated from a political antiapartheid and land restitution movement known as Hands Off District Six (HOD6) (District Six Museum, 2007). After the razing of homes and communities following the Groups Areas Act - displacing more than 6000 people - HOD6 successfully prevented the district from being redeveloped. They soon acquired a 'collection' of everyday objects, photo albums, songs and stories from former residents, and exhibited these traces in the old Methodist Church, one of the few buildings spared from the apartheid bulldozer. What was initially conceived as a temporary exhibition and social space for former residents has now become an internationally recognized museum that educates younger generations and visitors about the violent histories of apartheid. It also conducts research, offers intergenerational educational and facilitates public discussions on pressing issues.

Scholars have much to learn from projects such as site, Border Sutures and the District Six Museum, for they demonstrate the limitations of western understandings of memory, in particular the Aristotelian model that conceives of sites as passive surfaces or objects imprinted by the past (compare Forty, 1999). Rather than limit memory traces and historic sites to their material locations or interpret them as mere palimpsests, artists, activists and educators animate the multiple spacetimes of memory through their work. Renata Stih and Frieder Schnock's Orte der Erinnerung Denkmal/Places of Remembrance Memorial (1993) in Berlin-Schöneberg, for example, invites walkers-by to imagine the violence of historical laws through the aesthetic language of popular culture (Stih and Schnock, 2002, 2007). Residents may accidentally discover this network of 80 street signs in their neighborhood en route to the grocery store or local park; the brightly 
colored images of a loaf of bread, a cat, a mountain or a bench, depicted in an aesthetic form similar to advertisements or images in children's books may attract their attention. Upon closer inspection, the other side of each sign has a text referring to the image or (historic) locales: 'At Bayerischer Platz, Jews may sit only on yellow park benches. Eyewitness reports 1939.' When situated in the now mundane spaces of what was once a residential area known for its professional and upper-class Jewish community, these seemingly innocent signs permeate the comfortable world of everyday routine and ask viewers to move between past and present spaces of social exclusion, legal separation, expulsion, and murder in their city (see Figure 2).

Not only can scholars learn from such 'memorials' for the ways they question existing institutional structures of memory, they can also begin to consider the ways these projects explore the creative potential of time and space, memory and forgetting. 'Archaeographer' Michael Shanks (2007), for example, has developed a 'hybrid practice' of art-archaeology that troubles disciplinary divides and reconfigures institutional practices of stewardship and research. Working collaboratively with digital authorship, photography, and a virtual archival lab (Second Life), he experiments with concepts such as Traumwerk, deep mapping and deep time, the latter of which includes placeevents, incidental moments and percolating (multi)temporality. Rather than uncovering hidden histories, artist-scholars such as Shanks challenge dominant regimes of memory by creating spaces that revisit historical social relations and imagine new possibilities. In quite distinct ways, American Dakota multi-media artist and educator Mona Smith (2007) questions western practices of memory by acknowledging the presence of
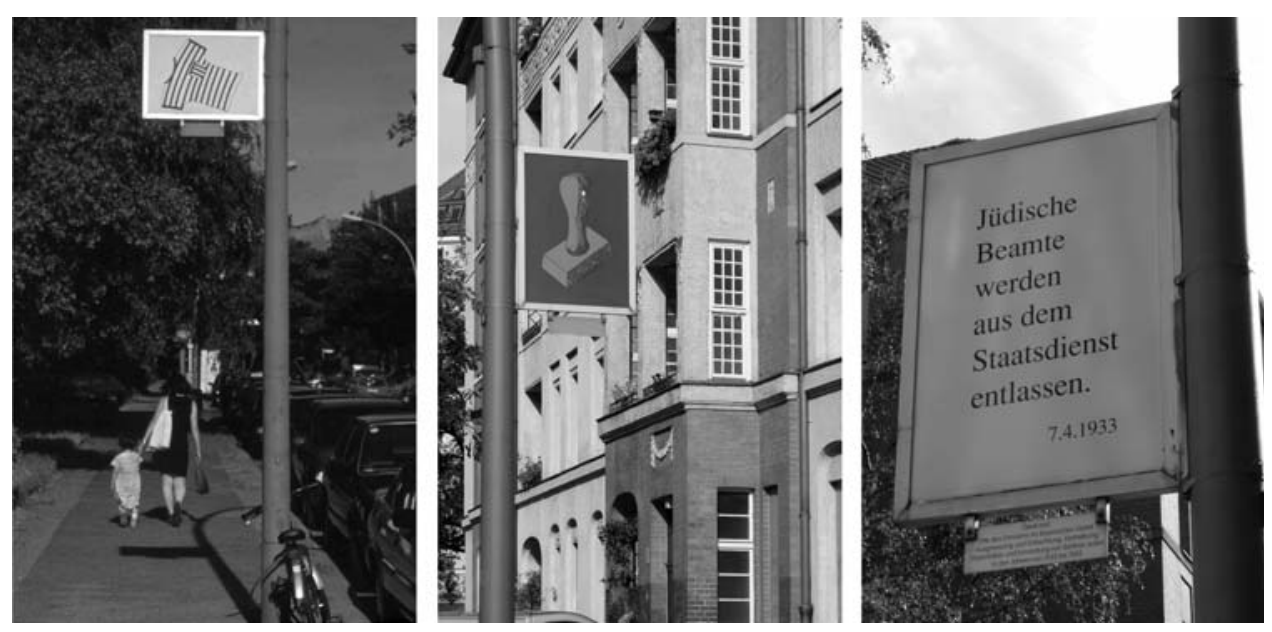

FIGURE 2 Denkmal: Orte des Erinnerns im Bayerischen Viertel/Memorial: Places of Remembrance in the Bavarian Quarter. Text on reverse side of striped T-shirt sign reads: 'All Jews over the age of 6 must wear a yellow star with the word "Jew" on it. September 1, 1941.' Text on reverse side of rubber stamp sign reads: 'Jewish civil servants may no longer serve the State. April 7, 1933.' @ Stih and Schnock, VG Bild Kunst Bonn/Berlin ARS, New York. Stih and Schnock, Memorial in the Bavarian Quarter, Berlin-Schöneberg (1993). Photographs courtesy of the artists. 
Dakota peoples in public space. Through temporary multi-media installations, such as 'Cloudy Waters' and 'City Indians', and in educational projects, including memory maps, community events and semi-permanent sound environments, visitors encounter multi-sensual historical narratives, Dakota stories, environmental memories and landscape experiences. As Smith explains: 'Dakota remember through land, experience (including ceremony), and story. Dakota people know that everything passes away, so buildings and signage and memorials are not the traditional ways to honor, to mourn, to remember. ${ }^{18}$

Smith's work calls attention to interior and exterior movements of memory through landscape, story and ritual. As I describe below, this is another reason why memory studies scholars should pay attention to artistic and activist practice: these projects explore the understudied relationships between embodied and shared memory.

\section{REVISITING LIFEWORLDS: BODY MEMORY, SUBJECTIVITY AND SOCIAL LIFE}

the vision: soft high pitched sounds enter gently through the space. Layered on top with muffled voices indistinct and whispering. A faint hammer drill begins to hum underneath. From the darkness a projected map begins to fade onto the back wall. It traces an old city, its bay, its streets, and its railway lines. The hammer drill begins to increase and decrease in volume like waves off the bay, each new wave successively louder. At a climax point a construction worker, wearing a white overall that acts as a screen, walks out of the map. She's been there all this time. We just haven't seen her. Lines of this foreign city mark her body while Prestwich Street (the burial site) is projected onto the contours of her face. She scratches her forehead. All sound ceases except for the gentle hum of the drill, faint, barely audible but present. She slowly lifts up her hand and begins to delicately brush along the projected detail on her torso. Her body remains motionless except for her hand which continues its journey along the ridges of her overall. She begins to speak.

(Talya Chalef, 2005, Australian National Trust grant application for site)

Through mappings, journeys, and bodies in motion, site reminds us that places are embodied contexts of experience, but also porous and mobile, connected to other places, times and peoples. The paths and storylines of the Prestwich Place burial ground were literally projected onto and incorporated into actress Tanya Heyward's body (see Figure 3). As she stumbled, crawled and ran through the spaces of Melbourne's abandoned colonial watch house, she became the archaeologist in one story, the ancestral spirit in another, the law in another, and the city is still another.

As humans move through and come to inhabit local worlds, bodies are connected to other bodies (including non-human lives and matter) in complex ways, even as the distinction between self and other is maintained through memories of intrasubjective experience. At the same time, if subjectivity is understood as a 'spatial disturbance' created 


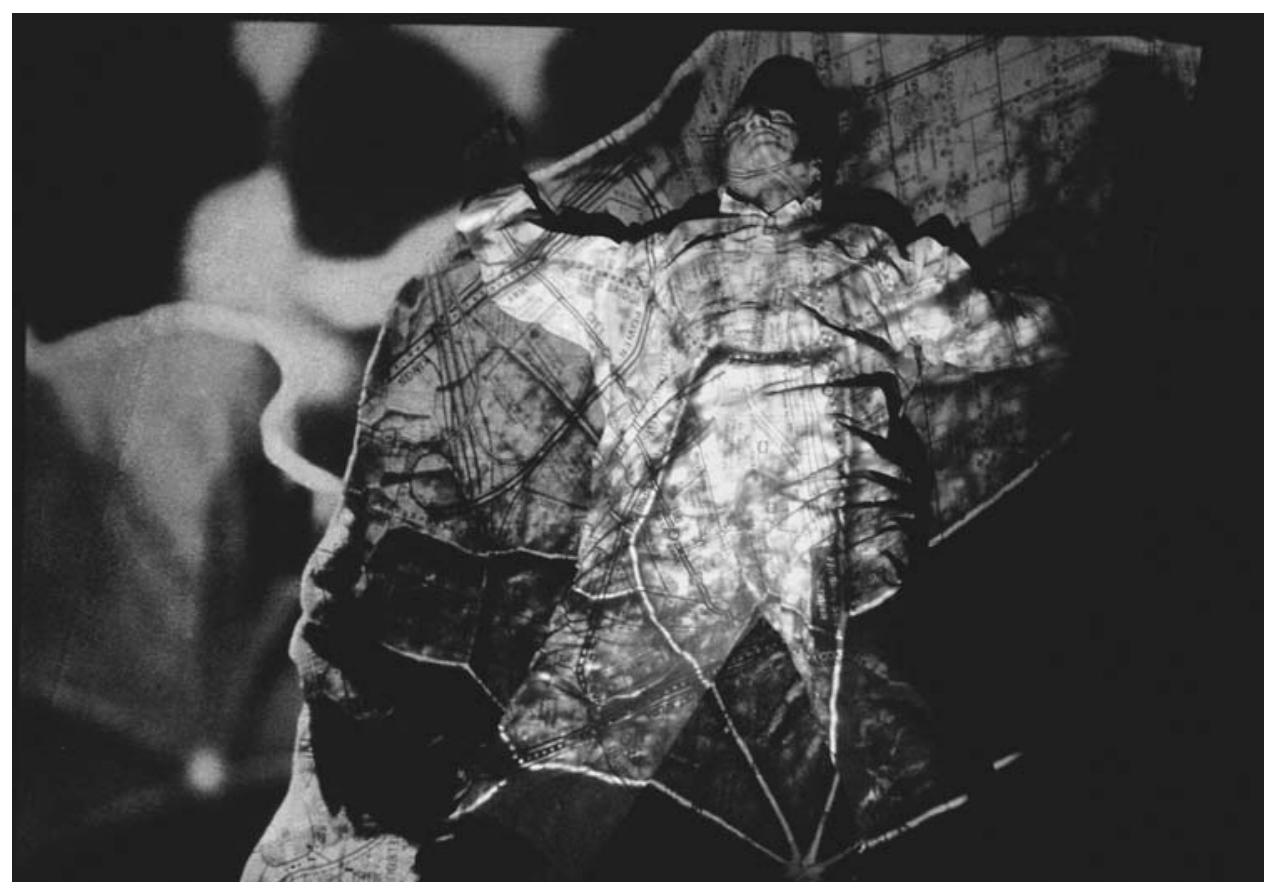

FIGURE 3 Performance artist Tanya Heyward in site, Melbourne Watch House, 2006 (C) Talya Chalef. Photograph by Bronwyn Pringle, courtesy of the artist.

by the unconscious - a rift that 'constitutes the subject and divides it from itself' psychic materialities, such as desire and sexuality, are more than memories of past encounters (Papoulias, 2003: 115). This complex interface between bodies, subjectivities and social life, however, remains under-explored in memory studies according to medical anthropologists Arthur and Joan Kleinman (1994). For the Kleinmans, bodily memory is often limited to discrete analyses of the brain, body, mind or person only. They introduce the concept of 'enacted assemblages' to account for the 'interconnected cognitive, affective, and transpersonal processes' of body-social memory (p. 719). Drawing upon Chinese conceptions of everyday life and social relations for their understanding of memory, the Kleinmans argue that the local interpersonal world is the primary means through which sociosomatic processes shape the body and bodily processes shape social space. Artistic performances too have relied upon embodied encounters with the everyday to explore intrasubjective relationships and knowleges not easily captured through language. As such, memory studies scholars have much to learn from these works to clarify the range of meanings associated with the term body memory.

Art theorist Jill Bennett (2003), for example, describes how visual artists evoke 'sensememory' to communicate non-linguistic, bodily forms of knowing and feeling. Bennett analyzed visitor responses to Dennis Del Favero and Justin Kramer's photomedia installations of sexual child abuse, and Marina Abramovic's self-mutilating performances, to identify how disturbing and empathetic spaces were created through visitors' bodily 
sensations. She argues that the visitors' squirms in response to viewing these works connect them to their own sense-memories, even though visitors know that the pain being depicted belongs to another. 'The image incites mimetic contagion acted out in the body of the spectator, which must continue to separate itself from the body of the other' (2003: 37). Thus, in contrast to discourse-based approaches to body memory (T. Bennett, 2003), and distinct from Aristotle's mneme (2000[350BC]), Bergson's notion of habit memory (1990[1911]), or neuro-cognitive models of procedural memory (after Antze, 2003), sense-memory is both emotional and cognitive, constituting a 'seeing' rather than 'thinking' truth that registers 'the pain of memory as it is directly experienced' to communicate 'a level of bodily affect' (J. Bennett, 2003: 29). ${ }^{9}$

At the same time, artists invite viewers to confront their own complicity in imagining violence through dominant visual media frames. Warning against the potential voyeurism of documentary images, journalist Philip Gourevitch was critical of media representations of the Rwandan genocide for its 'aesthetic assault of the macabre' (cited in Blocker, 2005: 182). For him, images may create 'excitement and emotion', but do not serve 'our understanding of the wrong' (p. 182; compare Sontag, 2003). In contrast, artist Alfredo Jaar made visible the impossible task of witnessing this horror through his 1995 installation Real Pictures (Blocker, 2005). Visitors walked into a room filled with dozens of black linen boxes that interred images of the Rwandan genocide. By encountering these sarcophagi with labels that reported their 'buried' contents hundreds of photographs taken by the artist in Rwanda and Zaire in 1994 - visitors had to choose if they would open these boxes or not. As they read the labels and imagined what lay within, their fear, excitement or other emotional-bodily responses may have triggered memories of habits of viewing. Art historian Jane Blocker (2005) argues that visitors were asked to witness themselves witnessing. Jaar's installation was not only critical of the media, but also of the fantasy of producing the documentary image through a neutral camera lens and innocent media viewer.

These examples point to the theoretical contributions artistic work offers to scholars about embodied and social memory. Yet artists and activists also offer models for socially engaged research practice. By way of conclusion, I briefly discuss societies that have experienced violence and loss, and how acknowledging the intimate relationships people have with wounded places may contribute to memory scholarship.

\section{WOUNDED PLACES: WITNESSING, HEALING AND MEMORY-WORK}

Using the story from Cape Town set against the backdrop of Australia, site explores the themes of memory, place and the politics of voice. It speaks of how the past surfaces in our 'everyday' and how we as a contemporary society need to deal with these intersections. When the skeletons of our past come back to haunt us, quite literally, how do we as a society respond to these hauntings? The discovery and remapping of these coordinates perform and embody our shared postcolonial 
condition, a condition that continues to haunt many individuals who carry unresolved traumas within them.

(Talya Chalef, 2005, Australian National Trust grant application for site)

In societies that have experienced violence, individuals return to particular places to revisit difficult feelings of loss, grief, guilt and anger (Fullilove, 2005; Till, 2005). People describe these places as having a distinct presence, one that is material, sensual, spiritual and psychic, yet also structured by social space (Adams et al., 2001; Tuan, 1977). As Jeff Kelly (1995) describes:

Places are what fill them [sites] out and make them work. Sites are like maps or mines, while places are the reservoirs of human content, like memory or gardens. ... Places are held in sites by personal and common values, and by the maintenance of those values over time, as memory. As remembered, places are thus conserved ... This conservation is at root psychological, and, in a social sense, memorial. But if places are held inside us, they are not solipsistic, since they can be held in common. At a given threshold, our commonly held places become communities ... .(p. 142).

I wish to suggest that places become part of us, even when held in common, through the intimate relationships individuals and groups have with them.

Places described as wounded are understood to be present to the pain of others and to embody difficult social pasts. For example, Bdote, the birthplace of the Dakota people in the contemporary American Midwest, is also a place of suffering, where more than 300 people died in a concentration camp (of the roughly 1700 imprisoned in 1862) and 38 people hanged following the US-Dakota wars - the largest mass execution in the history of the USA (Beane and Shoemaker, 2007)..$^{10}$ Yet at what is now known as historic Fort Snelling, the theft of ancestral homelands, the displacement of communities, and the bodily violence and murders experienced by local peoples during white resettlement are not acknowledged by the Minnesota Historical Center. Instead, this place is described as 'once a lonely symbol of American ambition in the wilderness', where visitors can participate in 19th-century reenactments of the Civil War and of ladies' teas (Minnesota Historical Society, 2007). For artist Mona Smith, 'without hearing a multitude of Dakota voices' in the contemporary landscape at wounded places such as Fort Snelling, the ancestral place of Bdote is wounded yet again. Bdote remains 'a painful reminder to Dakota people of what has been taken, what is lost. The mourning has barely begun. The wounds are not healed. And the injuries are worsened by the present use of the area.'11

Often the generations that come afterwards understand these places as material evidence of unspoken pain, in Caruth's (1996) words, crying wounds that demand justice. Being in the presence of a place that was important in the lives of loved ones may help individuals work through feelings of incompleteness - spectral traces that are passed through generations. As I have described for places in and near Berlin, through silent acts of witnessing and listening, wounded places allow individuals and groups to begin the difficult work of mourning loss (Till, 2005). I have come to pay particular attention to such intimate relationships people have with wounded places in cities as diverse as 
Berlin, Minneapolis, Cape Town and Buenos Aires as a result of my interactions with artists and activists. In quite distinct ways, all of these cities continue to be marked by segregation, displacement, racism and other forms of social and economic violence, but are also constituted by places that connect the living to former and future lives.

In countries undergoing political transformation, some wounded places continue to be cared for, even after the formal transition to democracy has been made. They are protected by individuals and groups as places of healing, where social networks and possible futures can be created, imagined and inhabited. In this way, wounded places are both a communal reminder of loss and a personal reserve for 'constructive forgetting' (Ricouer, 2004), both of which are central to mourning and embodied-social memorywork. As legal scholar Julian Jonker (2005) describes, memorial activist practices at District Six and Prestwich Place also 'prompt us to think about forms of descendancy, genealogies of proprietorship and histories of citizenship, and remind us that we need to reconceptualise received ideas of identity, belonging and the civic' (p. 204). Indeed in Cape Town, even as displaced ex-residents have slowly begun to return to District Six, the project of imagining a non-racial society remains tied to the deeply contentious processes of land restitution, legal claims to ancestry and heritage, nation building as reconciliation and economic recovery, all of which are marked by intergenerational silences.

Perhaps for this reason, the museum has begun a series of 'Hands On District Six' initiatives that materially connect displaced communities back to the wounded place of District Six, such as through public meetings, legal heritage interventions, conferences and festivals, and new planning proposals. The museum is also documenting placebased research practices in the communities whence families were displaced, acknowledging their contributions to public knowledge production. A series of 'memory methodology workshops', for example, invited Cape Town and township community leaders to exchange their memory projects and practices, and resulted in multisensual mappings, learning journeys and story-telling. ${ }^{12}$

The care that individuals and social groups give to maintain wounded places should not be surprising. Recent work in social psychology and urban sociology also highlights the significance of place for the environmental and psychological well being of individuals and communities (Klinenberg, 2002; Fullilove, 2005). As I have suggested here, by taking seriously artistic and activist place-based practice, not only do scholars have much to learn about memory theoretically and empirically; we can also begin building responsible research agendas that contribute to more socially just futures.

\section{Acknowledgements}

I wish to thank lain Biggs, Talya Chalef, Gerry Kearns, Mona Smith, Yi-Fu Tuan, and the participants of a Space\&Place/Land2 summer studio in 2007 for their insightful comments. I am also indebted to the participants of the 2005-06 Memory Methodology Workshop for their generosity and inspiring work, and to the British Academy Small Research Grant 40456 and the District Six Museum for funding the workshop series. These conversations have allowed me to think through these themes more richly. Any remaining errors are my own. Thanks also to Andrew Hoskins and the reviewers of this article for their constructive suggestions. 


\section{Notes}

1 This excerpt is an edited version of Chalef's program note, with generous permission of the artist. site was performed in Melbourne's Old Watch House in April 2006. For a video-clip and further details see Chalef (2006).

2 Elsewhere I discuss memory as a topic of inquiry and emerging field of study (Till, 2006). In addition to the launch of this journal, History and Memory (Indiana University Press) was established in 1988. A Memory Studies degree and research program exists at McGill University in Canada (http://www.memory.mcgill.ca/index.html).

3 By memory-work, I refer to the difficult process of working through the losses and traumas resulting from (revisiting) past violence and injustice, and of imagining more socially just futures (Till, 2005; Jelin, 2006).

4 The edited excerpts of Chalef's grant narrative to the Australian National Trust in this article were generously shared by the artist (personal communication, 2005).

5 Geographers distinguish between such concepts as site, situation, locale, landscape and place, as well as call attention to the interrelations between different kinds of space (absolute, relational, relative, symbolic, experiential). For a selection of the voluminous literature on place in geography, see Tuan (1977); Massey (1994); Adams et al. (2001); and Cresswell (2004). For an overview of place in the history of western philosophy see Casey (1997). In the arts, see ; Dorrian and Rose (2003); Kwon (2004); Dean and Millar (2005); Biggs (2006); place (2007).

6 Following Augé's publication of Non-places (1995), there has been a renewed discussion about lieux as opposed to non-lieux of memory, particularly in European circles.

7 Activists, historians and artists from multiple countries created two independent transnational networks in the late 1990s/2000s, the International Coalition of Memorial Museums to Victims of State-perpetrated Crimes (ICMEMO, 2007), based in Wewelsburg, Germany, and the International Coalition of Historic Site Museums of Conscience (2007), based in New York.

8 This quote is from the artist's proposal to develop a 'Language of the Earth' program at Fort Snelling, Minnesota. See the next section. The artist generously shared these materials (personal communication, 2007).

9 Bennett draws upon early work on trauma by Pierre Janet, work by French poet and Holocaust survivor Charlotte Delbo, Holocaust testimony studies by Lawrence Langer, the concept of 'encountered sign' by Gilles Deleuze and painter Francesco Clemente's idea of how affect is 'thought through the body'.

10 According to the Bdewakantunwan Dakota creation story, Bdote (Mendota in English) is the place of origins for the Dakota People. The violent history of this place has led to the 'Take Down the Fort' campaign: http://www.takedownthefort.com/

11 This quotation is from the artist's proposal to the Minnesota Historical Society, in memo form (personal correspondence, 2007).

12 I worked with and learned much from District Six Museum staff, in particular, Bonita Bennett, Chrischene Julius and Mandy Sanger, and research assistants Talya Chalef, Julian Jonker, Thozama Jonas and Rahmah Liang, all of whom helped conceptualize and coordinate the workshops. 


\section{References}

Adams, Paul, Steven Hoelscher and Karen Till (eds) (2001) Textures of Place: Rethinking Humanist Geographies. Minneapolis: University of Minnesota.

Antze, Paul (2003) 'The Other Inside: Memory as Metaphor in Psychoanalysis', in Susannah Radstone and Katharine Hodgkin (eds) Regimes of Memory, pp. 96-113. London: Routledge.

Aristotle (2000[350BC]) On Memory and Reminiscence, trans. J.I. Beare, The Internet Classics Archive. Available at: http://classics.mit.edu//Aristotle/memory.html

Augé, Marc (1995) Non-places: An Introduction to the Anthropology of Supermodernity, trans. John Howe. London: Verso.

Beane, Carly and Scott Shoemaker (2007) 'Reclaiming Bdote: Considering the Fort Snelling Historic Site', paper presented at 'Heritage Sites/Political Spaces' Space\&Place Symposium, April, University of Minnesota, USA.

Bennett, Jill (2003) 'The Aesthetics of Sense-memory: Theorising Trauma through the Visual Arts', in Susannah Radstone and Katharine Hodgkin (eds) Regimes of Memory, pp. 27-40. London: Routledge.

Bennett, Tony (2003) 'Stored Virtue: Memory, the Body and the Evolutionary Museum', in Susannah Radstone and Katharine Hodgkin (eds) Regimes of Memory, pp. 40-54. London: Routledge.

Bergson, Henri (1990[1911]) Matter and Memory, trans. N. Paul and W.S. Palmer. New York: Zone Books.

Biggs, lain (ed.) (2006) 'Art "After Landscape": Memory, Place and Identity', special issue of Journal of Visual Art Practice 5 (1\&2).

Blocker, Jane (2005) 'A Cemetery of Images: Meditations on the Burial of Photographs', Visual Resources 21(2): 181-91.

Border Art Workshop/Taller de Arte Fronterizo (2007) website. Available at: http://www.borderartworkshop.com/index.html

Caruth, Cathy (1996) Unclaimed Experience: Trauma, Narrative and History. Baltimore, MD: Johns Hopkins.

Casey, Edward (1987) Remembering: A Phenomenological Study (2nd edition). Bloomington: Indiana University Press.

Casey, Edward (1997) The Fate of Place. Berkeley: University of California Press.

Chalef, Talya (2006) site, Melbourne Old Watch House, April. Available at: http://www. talyachalef.com/performance-site.html

Cresswell, Tim (2004) Place: A Short Introduction. Oxford: Blackwell.

Dean, Tacita and Jeremy Millar (eds) (2005) Art Works: Place (Art Works). London: Thames \& Hudson.

District Six Museum (2007) website. Available at: http://www.districtsix.co.za/

Dorrian, Mark and Gillian Rose (eds) (2003) Deterritorialisations ... Revisioning Landscapes and Politics. London: Black Dog Publishing.

Forty, Adrian (1999) 'Introduction', in Adrian Forty and Susanne Küchler (eds) The Art of Forgetting, pp. 1-18. Oxford and New York: Berg.

Fullilove, Mindy Thompson (2005) Rootshock: How Tearing Up City Neighborhoods Hurts America, and What We Can Do About It. New York: One World Ballatine Books. 
Hayden, Dolores (1995) The Power of Place: Urban Landscapes as Public History. Cambridge, MA: MIT Press.

International Coalition of Historic Site Museums of Conscience (2007) website. Available at: http://www.sitesofconscience.org/

International Coalition of Memorial Museums in Remembrance of Victims of State-perpetrated

Crimes (ICMEMO) (2007) website. Available at: http://icom.museum/international/icmemo. html

Jelin, Elizabeth (2006) The Labors of Memory. Minneapolis: University of Minnesota Press.

Jonker, Julian (2005) 'Excavating the Legal Subject: The Unnamed Dead of Prestwich Place, Cape Town', Griffith Law Review 14(2): 187-212.

Jonker, Julian and Karen Till (2007) 'Thanatopolitics and Transition: Haunted Archaeologies of the Postcolonial City', paper delivered at the annual Association of American Geographers, April, Philadelphia, USA.

Kelly, Jeff (1995) 'Common Work', in Suzanne Lacy (ed.) Mapping the Terrain: New Genre Public Art, pp. 139-48. Seattle, WA: Bay Press.

Kester, Grant (2004) Conversation Pieces: Community and Communication in Modern Art. Berkeley: University of California Press.

Kleinman, Arthur and Joan Kleinman (1994) 'How Bodies Remember: Social Memory and Bodily Experience of Criticism, Resistance, and Delegitimation following China's Cultural Revolution', New Literary History 25(3): 707-23.

Klinenberg, Eric (2002) Heatwave: A Social Autopsy of Disaster in Chicago. Chicago, IL: University of Chicago Press.

Kwon, Miwon (2004) One Place After Another: Site-specific Art and Locational Identity. Cambridge, MA: MIT Press.

Lacy, Suzanne (1995) (ed.) Mapping the Terrain: New Genre Public Art. Seattle, WA: Bay Press. Massey, Doreen (1994) Space, Place and Gender, Minneapolis: University of Minnesota Press.

Minnesota Historical Society, Fort Snelling (2007) website. Available at: http://www.mnhs.org/ places/sites/hfs/

Nora, Pierre (1989) 'Between Memory and History: Les Lieux de Memoire', Representations 26: 7-25.

Nora, Pierre (1997) Realms of Memory. New York: Columbia University Press.

Papoulias, Constantina (2003) 'From the Agora to the Junkyard: Social Memory and Psychic Materialities', in Susannah Radstone and Katharine Hodgkin (eds) Regimes of Memory, pp. 114-30. London: Routledge.

Place (2007) website, Visual Art Research Centre, University of West England, Bristol. Available at: http://www. placeresearch.co.uk/

Rassool, Ciraj and Sandra Prosalendis (eds) (2001) Recalling Community in Cape Town. Cape Town: District Six Museum.

Ricouer, Paul (2004) Memory, History, Forgetting, trans. Kathleen Blamey and David Pellauer.

Chicago, IL and London: University of Chicago Press.

Shanks, Michael (2007) website. Available: http://documents.stanford.edu/MichaelShanks Smith, Mona (2007) Allies: media/art website. Available at: http://web.mac.com/alliesms/iWeb/ Allies/WELCOME.html Sontag, Susan (2003) Regarding the Pain of Others. New York: Picador. Stih, Renata and Schnock, Frieder (2002) Orte des Erinnerns: Ausgrenzung und Entrechtung, Vertreibung, Deportation und Ermordung von Berliner Juden in den Jahren 1933 bis 1945/ Places of Remembrance: Isolation and Deprivation of Rights, Expulsion, Deportation and 
Murder of Berlin Jews in the Years 1933 to 1945, Denkmal/Memorial in Berlin-Schöneberg (1993). Berlin: Haude \& Spenersche Verlagsbuchhandlung GmbH.

Stih, Renata and Frieder Schnock (2007) website. Available at: http://stih-schnock.de/ Till, Karen E. (2003) 'Places of Memory', in John Agnew, Katharyne Mitchell, Gearoid O Tuathail (eds) A Companion for Political Geography, 289-301. Oxford: Blackwell.

Till, Karen E. (2005) The New Berlin: Memory, Politics, Place, Minneapolis and London: University of Minnesota Press.

Till, Karen E. (2006) 'Memory Studies,' History Workshop Journal 62: 325-41.

Tuan, Yi-Fu (1977) Space and Place: The Perspective of Experience, Minneapolis: University of Minnesota Press.

KAREN E. TILL is Associate Professor of Geography and Codirector of the Space\&Place Research Collaborative at the University of Minnesota, USA. Her ethnographic research explores the interrelationships between place-making, personal and social memory, public art and cultural politics in contemporary cities. Her publications include: The New Berlin: Memory, Politics, Place (University of Minnesota Press, 2005); Textures of Place: Rethinking Humanist Geographies, edited with Paul Adams and Steven Hoelscher (University of Minnesota Press, 2001); and numerous book chapters and articles. She is currently working on two book-length projects, Remnant East Berlin and Wounded Cities. Address: Department of Geography, University of Minnesota, 414 Social Science Tower, 267-19th Avenue South, Minneapolis, MN 55406, USA. Email: ktill@umn.edu 